\title{
Ethics of responsibility in a theological perspective
}

\author{
Wolfgang Huber \\ Stellenbosch University \\ Stellenbosch, South Africa \\ w-k.huber@t-online.de
}

\begin{abstract}
In the article the author explicates his own view of a theological ethics of responsibility in dialogue with other proponents of such an ethics. A distinction is first made between an "ethic or responsibility" and an "ethics of responsibility". Attention is then given to the emergence of the key term of "responsibility" in Western culture and its theological origin pointed out. It is argued that responsibility as an ethical concept implies the accountability of human persons for their deeds before an ultimate instance of accountability and thus with inner necessity depends on an affirmative understanding of autonomy and self-determination. What is, however, also implied is dependence on human interaction and communication. From this follows the conclusion that the ethics of responsibility is based on a relational rather than an essentialist anthropology. This conclusion is confirmed in an extensive discussion of the views of the two most important representatives of a theological approach to the ethics of responsibility, namely Dietrich Bonhoeffer and H. Richard Niebuhr. In the last part of the article it is argued that what distinguishes theological ethics of responsibility is that contrary to a purely future-oriented ethics - as is the case with, for example, the ethics of responsibility of Max Weber and Hans Jonas - it is an ethics that intertwines the three modi of time: past, present and future.
\end{abstract}

\section{Keywords}

Dietrich Bonhoeffer; ethic of responsibility; ethics of responsibility; Hans Jonas; $H$. Richard Niebuhr; Max Weber; theological ethics. 


\section{I}

This article is based on a paper I read at a seminar on the theme "In search of an ethics of responsibility for our time."1 I was invited to participate in the seminar by Etienne de Villiers, one of the organisers. He recently published a remarkable book based on thorough research with the title Revisiting Max Weber's Ethic of Responsibility. ${ }^{2}$ What puzzled me somewhat is that in the title of the book the designation "ethic of responsibility" is used, while the reference in the theme of the seminar is to "ethics of responsibility". It led to reflection on my side on whether I should call the topic of my presentation "ethics" or "ethic of responsibility in a theological perspective". Let me briefly explain the result of my reflection, beginning with a word on morality.

By morality I understand the ensemble of human answers to moral challenges. The two most basic moral challenges are referred to in the two questions of Leo Tolstoy: "What should we do? How should we live?" In these questions two levels can be observed. One level has to do with the "right" to which every human person is obliged. When we are looking for those moral principles that are universal in character we are in the field of the "right". When we are looking for strong answers to the question on how we as individuals ought to lead our lives or how we as specific groups ought to shape our living together, we find ourselves in the field of the "good". Some people propose to identify the "right" with morals or morality and the "good" with ethics. But that complicates the problem, because it leads to a double meaning of ethics. Therefore, I decided to avoid this kind of language and to distinguish within morality the dimensions of the "right" and of the "good". 3

1 The seminar held at the Stellenbosch Institute for Advanced Studies on 17 January 2020 was the initiative of the Centre for Applied Ethics of the University of Stellenbosch and the Dawid de Villiers Memorial Lectures, under the auspices of the Faculty of Theology at the same university.

2 Etienne de Villiers, Revisiting Max Weber's ethic of responsibility (Tübingen: Mohr Siebeck, 2018).

3 Cf. Wolfgang Huber, Ethics: The Fundamental Questions of Our Lives (Washington DC: Georgetown University Press, 2015), 7-10. 
To follow Peter Singer, "ethics" means not morality itself, but "the field of study, or branch of inquiry, that has morality as its subject". ${ }^{4}$ Singer thinks that philosophy is the only academic discipline that has properly to do with this inquiry on morality. He is, however, willing to admit that other areas of study, from anthropology to theology, also deal with it. And he takes into account that in more recent times the term "ethics" is also used as a synonym for morality itself. For our purpose I use the term "ethics" only for the inquiry or study of morality.

For a German-speaking person it is very difficult to grasp the difference between ethics and ethic, because this difference does not exist in German. (In German we would, seldom enough, use the plural "Ethiken" only for a plurality of books on ethics or a plurality of fields of applied ethics). The difference between the two English terms seems linguistically to be very intricate - the plural noun "ethics" goes regularly with a verb in singular. Therefore, it is not inaccurate when we always translate "ethics" (plural) in German with "Ethik" (singular). But how should we translate the singular noun "ethic" into German? It seems to be near to the term "Ethos" in its German understanding. ${ }^{5}$ A possible understanding of "ethic" might be: the principles or guidelines of right and wrong characteristic for an individual, a social group or a culture. Trump's ethic, for instance, includes the principles or guidelines of right and wrong held (if any) by Mr. Trump; Puritan ethic includes the principles or guidelines of right and wrong accepted by the Puritan movement. There are interesting cases in which the difference of singular and plural, of "ethic" and "ethics" plays an important role. "Military ethic" means the ethic of soldiers, "military ethics" means the inquiry and research in a specific field of applied ethics. "Work ethic" means the principles or guidelines of right and wrong applied by those who identify the central meaning of life with a specific kind of human activity. "Work ethics" means the study of moral problems related to the understanding and the conditions of human labour.

4 Peter Singer, 'Ethics', in Encyclopaedia Britannica (https://www.britannica.com/topic/ ethics-philosophy, last accessed on 02.01.2020).

5 The "Stiftung Weltethos" translates Hans Küng's term of "Weltethos" with "global ethic" [Online]. Available: https://www.global-ethic-now [Accessed: 02.01.2020]. 
"Ethic" could therefore be understood as a specific kind of morality, "ethics" would rather mean the research or investigation in a specific field of morality. "Ethic of law", for example, would refer to the theological distinction of a certain type of morality for which in German the term "Gesetzesethik" is used. "Ethics of law" would refer to the research field indicated in German by the term "Rechtsethik". Max Weber's "ethic of responsibility" would refer to a specific understanding of morality related to the key word of responsibility, which could, in Weber's opinion be distinguished from an "ethic of conviction", whereas "ethics of responsibility" means ethical research or investigation under the guiding principle of responsibility.

I will argue that an ethics of responsibility as a kind of ethical research gets a specific profile when seen from a theological perspective. For that purpose, I will take a next step in a continuous endeavour in which I have been involved for no less than four decades. ${ }^{6}$ But also this next step will by no means lead to the end of this adventurous road.

\section{II}

Ethics of responsibility occurs not only as a theological undertaking. We encounter it in different academic fields and in a number of variants. It seems that the term entered the stage of academic dispute in the famous lecture on "Politics as vocation", a lecture delivered in 1919 by a sociologist - Max Weber - who replaced the earlier term of "ethic of success", used for instance by the philosopher Max Scheler, with the term "ethic of responsibility." It was Weber's intent to use a distinctly secular term for this ethic and to oppose it to the ethic for which a rather

6 Cf. Wolfgang Huber, Folgen christlicher Freiheit. Ethik und Theorie der Kirche im Horizont der Barmer Theologischen Erklärung (Neukirchen, 1985); Huber, Konflikt und Konsens. Studien zur Ethik der Verantwortung (Munich, 1990); Peter Dabrock / Siegfried Keil / Wolfgang Nethöfel (eds.), Verantwortungsethik als Theologie des Wirklichen (Göttingen, 2009); Wolfgang Huber, Christian Responsibility and Communicative Freedom. A Challenge for the Future of Pluralistic Societies, edited by Willem Fourie (Berlin-Zürich, 2012); Huber, Von der Freiheit. Perspektiven für eine solidarische Welt (München, 2012); Willem Fourie, Communicative Freedom. Wolfgang Huber's Theological Proposal (Berlin-Zürich, 2012).

7 Max Weber, 'The profession and vocation of politics', in Political Writings (Cambridge, UK: Cambridge University Press, 1994), 309-369; Weber, Wissenschaft als Beruf 1917 11919. Politik als Beruf 1919. Studienausgabe (Tübingen, 1994); Etienne de Villiers, 
religious term, namely "ethic of conviction", was used. The term "ethic of responsibility" gained additional importance when the debates on "limits to growth", genetic engineering and organ transplants provoked a new debate on ethical answers to scientific and technological developments. It was the philosopher Hans Jonas who with his Imperative of Responsibility of 1979 set the tone for this new debate. ${ }^{8}$

In the sociological, philosophical and also political debates on "responsibility", seen as the appropriate response to the ethical challenges of our times, it was seldom considered, that a term of theological origin was used as a brand for a new kind of ethical reflection. The ethical use of the term is not as young as some may expect. The term has a long history that goes back to the $16^{\text {th }}$ century. In its structure it is characterised by a relationship in which three instances are involved: A person is accountable for something or someone before a third party, for instance a judge. ${ }^{9}$ The words "responsible" and "responsibility" came to be used in German, as well as in English, in the second half of the $16^{\text {th }}$ century. The juridical use referred to the accountability before a worldly judge. But from the beginning a metaphorical transfer occurred from the juridical to the theological aspect of accountability. And that was quite understandable because the metaphoric use of the model of the court and the judge occurred already in the New Testament and was therefore familiar not only in theological but also in common language: "For we must all appear before the judgment seat of Christ, so that each of us may receive what is due us for the things done while in the body, whether good or bad." ${ }^{10}$ In the juridical as well as in the theological use responsibility is primarily seen as a retrospective liability for deeds in the past and their consequences

Revisiting Max Weber's Ethic of Responsibility; Max Scheler, Der Formalismus in der Ethik und die materiale Wertethik (Halle a.d.S, 1916),109-162.

8 Hans Jonas, Das Prinzip Verantwortung: Versuch einer Ethik für die technologische Zivilisation (Frankfurt a.M: 1979); Jonas, The Imperative of Responsibility: In Search of an Ethics for the Technological Age (Chicago, IL: 1994); Jonas, Das Prinzip Verantwortung (Kritische Gesamtausgabe Bd. I 2, 1+2), eds. Dietrich Böhler / Bernadette Hermann (Freiburg i.Br: 2015, 2017); cf. Wolfgang Huber, ,Ehrfurcht vor dem Heiligen. Zur Aktualität des 'Prinzips Verantwortung'. Pastoraltheologie 107 (2018): 411-426.

9 Hans-Richard Reuter, "Verantwortung”, in Reiner Anselm / Ulrich H.J. Körtner (eds), Evangelische Ethik kompakt. Basiswissen in Grundbegriffen (Gütersloh, 2015), 212-218.

102 Cor 5:10 NIV. 
before the judge. In both cases responsibility is normally related to deeds that are either intrinsically or in their consequences evaluated as negative. It took long before responsibility became to be also used in a positive sense as alternative for "duty", "vocation" or comparable terms to describe ethically valuable tasks or acts. This does not take away that already in the eschatological perspective of the parable on the final (Mt 25), not only negative but also positive deeds towards the poorest neighbours are seen as decisive for the judgement of the heavenly judge. This is underlined in the words in which the king-judge identifies himself not only with those who were neglected but also with those who were helped in their need. It is not only said: "Truly I tell you, whatever you did not do for one of the least of these, you did not do for me, but also: "Truly I tell you, whatever you did for one of the least of these brothers and sisters of mine, you did for me."11

There is an obvious tension between this narrative of a last judgment according to deeds with its definite separation of the sheep and the goats and the message of reconciliation or atonement by God's grace alone. The biblical emphasis on a final responsibility of every human person for her deeds is undeniable. Moral responsibility is not eliminated by the certainty of faith that God overcomes human sinfulness and restores his relationship to humans by his grace. Both theological concepts seem to be important. But they can be held together only by a differentiation between the person and her deeds. The person is responsible but not identical with her deeds. Salvation remains possible.

With the transition of the term from the juridical and theological areas into the field of ethics "responsibility" is mostly used with respect to the question of determinism and free will. You can only speak about individual responsibility if a person is accountable for her deeds and their consequences. Behind the term lies the tension between the determination of a person's deeds by external factors and the freedom of the person, in the sense of being capable to initiate actions. A precondition for any ethics might be seen in the necessity to make plausible the compatibility of determination and free will or to argue for the autonomy of the person irrespective of the fact that freedom of the finite human person is a limited

11 Mt 25:45, 40 NIV. 
freedom in itself. Any reference to responsibility implies a concept of autonomy and self-determination.

Autonomy means the fundamental capability of the human person to develop by herself reasonable arguments with regard to moral issues, to communicate with others on the right way of dealing with actual challenges and to come to justifiable decisions. Self-determination means that every individual has the right and the opportunities to plan their own actions, to search for appropriate means and to realise their plans alone or together with others. Self-determination is a basic anthropological concept; its realisation depends on concrete external conditions. Self-determination belongs at the same time to the basic claims in every kind of living together in community. The right of self-determination belongs therefore to the basic rights, wherever a community is governed by the rule of law. It is important to observe that autonomy and self-determination, as described in these few sentences, do not include only an individual but also a communicative or cooperative dimension.

Responsibility as an ethical concept implies the accountability of human persons for their deeds or their failures before an ultimate instance of accountability. This concept depends with inner necessity on an affirmative understanding of autonomy and self-determination. Only under the assumption that human persons are moral agents we can apply the idea of responsibility to their deeds. Therefore, we do not have to choose between an ethics of freedom and an ethics of responsibility. The ethics of responsibility clarifies what an ethics of freedom implies. Wherever a society is based on strong assumptions with regard to autonomy and self-determination this society is obliged to strengthen the capabilities of the individuals to make use of their self-determination and to exert their responsibility. Enabling justice is therefore the crucial virtue of a just, participatory and sustainable society.

Under such a perspective the distinction between an ethic of responsibility and an ethic of conviction only relates to the criteria under which an autonomous and self-determined agent has to probe whether he or she acted responsibly or not. In the case of an ethic of conviction the criterion is seen in binding maxims or rules. In the case of an ethic of responsibility the criterion relates to the anticipated results and consequences. An ethic of 
conviction follows a Kantian categorical imperative for which the maxim of an action is proved under the perspective of its possible generalisation. An ethic of responsibility follows a kind of categorical imperative formulated by Hans Jonas for which the consequences of an action is proved under the perspective of its compatibility with the future of a truly human existence on earth. Both concepts of ethic are, in this view, special cases to be studied in the framework of an ethics of responsibility. An ethic of responsibility according to Weber, as well as to Jonas, is not more than a specific case of an ethics of responsibility from a theological perspective.

\section{III}

In order to develop this kind of ethics further, we have to have a look at the anthropological assumptions implied in the described concept. They start with the idea that every human person is accountable for her way of living. Under the perspective of moral responsibility, we get a specific access to the equality of human persons. The idea is that people in their difference are equal in their responsibility as well as in their rights. That does not exclude but implies that we understand the subjects of these equal rights and equal responsibilities as interconnected and interacting. Autonomy and self-determination on the one, communication and cooperation on the other side are interrelated. The responsible self has to be understood as a relational being. It is not enough to say that every individual life has a social aspect as a secondary element added to the primary aspect of individuality as self-esteem. Ethics of responsibility is based on relational rather than on essentialist anthropology. Essentialist anthropology identifies the "substance" in human persons that makes them human; relational anthropology identifies the relationships of human persons that make them human. Essentialist anthropology takes for instance reason as the "substance" of being human; relational anthropology sees humans as responsive and therefore responsible beings.

This distinction plays an important role in theology. The understanding of the human person created in the image of God in the creation narrative ${ }^{12}$ is differently interpreted in Christian theology with respect to the alternative

12 Gen 1:26f. 
between essentialist and relational concepts. The essentialist interpretation relates the two terms used in the biblical narrative on the creation of human beings made in the image of God. Not only the term "image" (imago) but also the term "similarity" (similitudo) is used in this context. Whereas under the influence of the original sin the similarity between God and the human person disappears, the image continues to exist. There is a substantial continuity of the human person before and after the Fall. The relational interpretation sees the creation of the human person in the image of God as a relatedness between God and his creature. The influence of the human separation from God through the human person's sinful rotation around herself distorts her relationship to God, but this relationship gets renewed by divine love and grace, because God himself does not give up his relationship to the human person even being a sinner. The biblical narrative sees the human person addressed by God and called to an answer. The human person is understood as an answering, responsive and therefore responsible being. In shaping this narrative in a more systematic manner we may distinguish between four dimensions of this human relatedness: to God, to the world, to other humans, to oneself.

The most remarkable theological approaches to the ethics of responsibility during the 20th century made use of such a kind of relational anthropology. Dietrich Bonhoeffer as well as $\mathrm{H}$. Richard Niebuhr understood the human person as answerer, as responder.

\section{IV}

Dietrich Bonhoeffer, in the fragments for his Ethics, developed his concept of responsibility in 1942, in a time in which he was deeply involved in his conspiratorial activities. It is amazing to which extent his manuscripts explicitly reflect the situation of resistance, including the problem of tyrannicide. But at the same time, he developed a clear conception of an ethics of responsibility. But he does so without using the term "ethics (or ethic) of responsibility". If I see correctly, this term never shows up in his book. Even when he refers to Max Weber, he does so without reference to the term "ethics of responsibility". It is the concept of responsibility itself, not a concept of an ethic or ethics that attracts his interest. 
His starting point can be found in the following sentences: "This concept of responsibility denotes the complete wholeness and unity of the answer to the reality that is given to us in Jesus Christ, as opposed to the partial answers that we might be able to give, for example, from considerations of usefulness, or with reference to certain principles. In light of the life that encounters us in Jesus Christ, such partial answers will not suffice, but only the complete and single answer of our life. Responsibility thus means to risk one's life in its wholeness, aware that one's activity is a matter of life and death."13 Bonhoeffer develops his understanding of responsibility in a transformation of the Lutheran concept of vocation. He is not, or not longer, only interested in God or Christ calling a person to discipleship, to obedience. This interest dominated his book on Discipleship with its key sentence: "Only the believers obey, and only the obedient believe." ${ }^{14}$ In his Ethics he is not only interested in the human person as obedient believer and believing obedient, but as answerer, as responder. So, his interest moves to the interaction between call and answer. The vocation is seen from the perspective of the person who calls. The addressee is asked to respond to this call. The vocation is understood as an activity of God in Christ. The response is a human activity. The appropriate term for this response is "responsibility". Bonhoeffer changes the traditional understanding in the way in which he establishes a relationship between Christ's calling and the human answer, the human responsibility. "From Christ's perspective this life is now my vocation; from my own perspective it is my responsibility." 15 Bonhoeffer takes the example of Jesus to clarify how obedience and freedom or, as he now prefers to formulate, the commitment to human beings and to God and the freedom of our own life together determine the structure of responsible life. This responsible life is the answer to God's call, to his vocation.

Bonhoeffer chooses this new view of the relation between "vocation" and "responsibility" also on other grounds. When Luther coined the term "vocatio" ("Beruf"), he did not restrict the meaning of the term

13 Dietrich Bonhoeffer, Ethics (DBWE 6; Minneapolis, MN: Fortress, 2005), 254. Cf. Wolfgang Huber, Dietrich Bonhoeffer - Aufdem Weg zur Freiheit. Ein Porträt (München: C. H. Beck, 2020), 209-232.

14 Dietrich Bonhoeffer, Discipleship (DBWE 4; Minneapolis, MN: Fortress, 2001), 63.

15 Bonhoeffer, Ethics, 290. 
to the professional tasks of an individual, but saw tasks in the personal, professional and public fields of human activities as comparable expressions of one's calling. But in later times, more exactly during the transition to the industrial era, the term "vocation" was more or less exclusively restricted to the professional tasks of a person. That was specifically the case in German-speaking areas, because the German language does not know a clear difference between profession and vocation; "Beruf" includes both of them. During the transition to the industrial era the "statistics of profession" ("Berufsstatistik" were restricted to the enumeration of existing professions and the amount of people active in these different fields.

That created remarkable linguistic difficulties for the tradition of the protestant ethic of profession, based on the Lutheran idea of a specific divine call (vocation), to which the individual has to stick - according to St. Paul's saying: "Each person should remain in the situation they were in when God called them." 16 But for Bonhoeffer it was clear that the answer to Christ's calling could by no means be restricted to the professional area. In order to illuminate the broader horizon of responsibility, he understood work, family, politics and church as four mandates, that means four areas, in which human persons are confronted with the divine call, God's commandment. In all these fields they have to react with commitment in a free, responsible answer.

A restriction to one of these fields was excluded. Bonhoeffer was convinced, "that the response to the call of Jesus Christ might in a concrete case [even] consist in leaving a particular earthly vocation in which it is no longer possible to live responsibly." ${ }^{17} \mathrm{He}$ had in mind the situation of resistance against the Nazi regime, in which responsibility had to be practiced outside the normal, well-defined field of professional activities. The area of responsibility is the struggle for the common good. When we nowadays distinguish between personal, professional and political (or institutional) ethics, we can easily see that all three fields put the ethical subject before specific questions of responsibility. Ethics of responsibility can therefore not be restricted to the field of political, social or institutional ethics (or whatever you like to name this field of ethical reflection). Ethics of

161 Cor 7:20 NIV,

17 Bonhoeffer, Ethics, 291. 
responsibility includes - in my distinction - likewise the fields of personal, professional and political ethics. Otherwise you would not take seriously the anthropological basis of this kind of ethics, namely the relational anthropology in which human persons are understood as communicative beings, as people, listening to their call and answering it. And you would also not take seriously the theological basis of this kind of ethics that deals with the dialectic of commitment and freedom, or - as the sociologist Ralf Dahrendorf used to say ${ }^{18}$ - of ligatures and options.

This togetherness of commitment and freedom is constitutive for what Dietrich Bonhoeffer calls the "the structure of responsible life". Commitment and freedom together define this structure. On the side of commitment Bonhoeffer accentuates deputyship for those who need assistance and realism in dealing with given challenges. On the side of freedom, he emphasises the venture of accountability and the preparedness to become guilty. The most important influence of commitment on the side of freedom can be seen in the fact that Bonhoeffer understands freedom not as a life in possibilities but as encounter with reality, as he describes it in a poem from the time in prison: "Not always doing and daring what's random, but seeking the right thing, / Hover not over the possible, but boldly reach for the real. Not in escaping to thought, in action alone is found freedom." 19

\section{V}

H. Richard Niebuhr is the second remarkable classic who introduced the concept of responsibility into Protestant theology. ${ }^{20}$ If I see it correctly, this author also did not use the term "ethics or ethic of responsibility", but chose "responsibility" as the key word for his approach to ethics. Not "responsible

18 Ralf Dahrendorf, Der moderne soziale Konflikt. Essay zur Politik der Freiheit (Stuttgart, 1994).

19 Dietrich Bonhoeffer, Letters and Papers from Prison (DBWE 8; Minneapolis, MN: 2010), 513.

20 For the newest short information about Niebuhr as ethicist see Christian Polke, 'H. Richard Niebuhr'. Zeitschrift für Evangelische Ethik 64(2009): 69-72; on his understanding of revelation see Hans Joas, 'Re-lecture: H. Richard Niebuhr, The Meaning of Revelation', in Lebendige Seelsorge. Zeitschrift für praktisch-theologisches Handeln 70 (2019): 368-369. 
life" (as in the case of Bonhoeffer), but "the responsible self" is at the centre of Niebuhr's ethics. That accentuates the interest in an anthropological foundation of ethics. And it makes clear that this foundation has to be found in a relational anthropology, for which Niebuhr refers to the "I-Thou-relation" in the dialogical philosophy of Martin Buber, but even more to American pragmatism, mostly to George Herbert Mead, who was pioneering in the understanding of the human self as a self in relationships from an empirical basis, especially in social psychology. Niebuhr probably for the first time got acquainted with the thinking of G.H. Mead during his studies in Chicago in the early twenties of the $20^{\text {th }}$ century. His step from Buber to Mead is of specific importance, because Niebuhr takes from Mead a sensitivity for the not only the dual but the triple structure of the interpersonal relationship. In interpersonal interactions a third element is always present - may it be a thing, a plan, an idea or a sentiment. As Hans Joas describes, Niebuhr's thinking over the years became to be influenced "stronger and stronger" by thinkers who emphasised the semiotic and interpersonal dimensions of human existence. ${ }^{21}$

This understanding of the human person as a self in relationships is of special importance in Niebuhr's book on The Responsible Self, published in 1963, one year after Niebuhr's death. However, he started his reflections on the topic already (at least) around the same time as Bonhoeffer, but there was no interaction between the two (even if his brother Reinhold might have told him about his German student and friend). In the years in which Bonhoeffer - in parallel to his conspiratorial activities - developed his concept of responsibility $\mathrm{H}$. Richard Niebuhr struggled in a series of essays on the topic of war with the same problem. ${ }^{22}$ In the first period his primary interest is directed towards the responsibility of the Christian church. In an article on "The Christian Church in the World's Crisis" he describes the life of the church as a continuous process of actions, in which her

21 Hans Joas, Interpretation and Responsibility: A Synthesis of Mead and Troeltsch? Unpublished paper 2019. Cf. Hans Joas, Praktische Intersubjektivität. Die Entwicklung des Werkes von George Herbert Mead (Berlin, 2000 [1980]).

22 According to Douglas F. Ottati, 'The Niebuhrian Legacy and the Idea of Responsibility'. Studies in Christian Ethics 222.4 (2009), 399-422 (404). The language of responsibility and even the term "responsible self" appear first in H. Richard Niebuhr, "The Question of the Church', in H. Richard Niebuhr / Wilhelm Pauck / Francis P. Miller, The Church against the World (Chicago 1935), 4, 12. 
responsibility is at stake. Concrete decisions, especially on participation or non-participation in war, have to be critically proven in a broader context in order to find out, whether self-regarding fears, nationalist faiths, other motives, or the faith in God and in God's universal cause determine the different proposals. ${ }^{23}$ In three articles of 1942/43 for Christianity and Crisis Niebuhr pushes his argument a decisive step further. Douglas Ottati summarises Niebuhr's central thesis as follows: "In the war, God is judging our self-righteous assertions of our own limited national and economic interests in crucifying events, such as the bombings of children in Cologne and Coventry - events in which the innocents suffer for sins of the guilty. As responsible agents who view ourselves and our world in relation to this God, our appropriate reply to these nightmarish events, whether we participate directly in the fighting or not, is repenting selfcriticism, coupled with a resolve to reconcile with enemies when the war is ended." 24 That is very near to the famous confession of guilt of Dietrich Bonhoeffer, written down in $1941 .{ }^{25}$ Both of them, living on different sides of the "nightmarish events" emphasise in comparable clarity the necessity of "repenting self-criticism" as precondition for any responsible action of the church. After the end of World War II Niebuhr goes on to describe his understanding of the universal responsibility of the church that cannot be restricted to the interests of the own nation or the own church. ${ }^{26}$ But in a next step he goes beyond the reflection on the church as subject of responsible Christian action. He asks, in which way every human person can be seen and has to be seen as a responsible actor.

For that purpose, he starts to develop a systematic understanding of the "responsible self". ${ }^{27}$ That is the time in which he introduces the distinction between responsibility to and responsibility for as the two main dimensions

23 H. Richard Niebuhr, 'The Christian Church in the World's Crisis', in Christianity and Crisis (Summer 1941): 11-17 (Cf. Ottati, 'Niebuhrian Legacy', 405).

24 Ottati: Niebuhrian Legacy, 405.

25 Bonhoeffer, Ethics, 134-145.

26 H. Richard Niebuhr, 'The Responsibility of the Church for Society (1946)', in H. Richard Niebuhr, The Responsibility of the Church for Society and Other Essays, ed. Kristine A. Culp (Louisville, KY 2008), 62-75.

27 H. Richard Niebuhr, 'The Ego-Alter-Dialectic and the Conscience'. Journal of Philosophy XLII (1945): 352-359. 
of responsibility. Together with the actor as subject of responsibility that describes a triple relationship. After World War II, Niebuhr develops this concept in his lectures, summarised in the Robertson Lectures in Glasgow 1960 and published posthumously in 1963 as The Responsible Self. We may see this book as prolegomena for his ethics. The whole concept was presented again and again at Yale University's Divinity School where Niebuhr served as professor for thirty years - an academic teacher, whom Charles West called "one of the greatest theological professors of all times"28. Unfortunately, these lectures never were published. We have no more than the prolegomena in the form of The Responsible Self.

Niebuhr chose for his Robertson Lectures in Glasgow in spring $1960^{29}$ the subtitle "An Essay in Christian Moral Philosophy". He was interested in a kind of theological ethics that was developed in a dialogue with philosophy, social science and the humanities. His point of reference was not, as in other cases, the hermeneutical approach of Ernst Troeltsch - intentionally combined with Karl Barth's Theology of Revelation. The background of his theory of responsibility was not a theological school (Troeltsch and Barth being for different reasons his favourites), but the already described insight of George Herbert Mead that the subject is not constituted by its individual consciousness but emerges from processes of interaction. This theoretical concept paved the way for the relational interpretation of the "responsible self”.

Niebuhr clarifies his anthropological concept by the distinction between the human person as maker, as citizen and as responder. The maker is oriented towards products or results; the corresponding kind of ethics is teleological ethics. The citizen is oriented towards rules of common life, towards the law; the correspondent kind of ethics is deontological ethics. The responder concentrates his awareness on the challenges of a given situation and on the possible outcome of present actions: he looks for actions that fit into a given situation and are helpful for all people involved.

28 Charles West, 'Review of H. Richard Niebuhr, The Responsible Self'. Theology Today 21, no. 4 (1965): 519-522.

29 According to the son Richard R. Niebuhr this version forms the basis for the publication. The text was in an altered form also presented as the Earl Lectures at the Pacific School of Religion in Berkeley/CA and in a series of addresses at the Riverside church in New York City (Preface to The Responsible Self, 3). 
With this third model Niebuhr overcomes the well-established distinction between teleological and deontological ethics by a third concept. His thinking in relational terms is not only applied to the interactional character of the human person, but also to the relational character of values. Also, their understanding depends on their point of reference. That question of reference makes his ethics explicitly theological. Values are in his understanding values in relationship to God.

As theological as this approach is as far is it from any kind of biblicism. Niebuhr is convinced that in traditional forms of theological ethics the reference to biblical texts is exaggerated. If we take the relational character of the human person seriously, theological ethics does not emerge from the moral wisdom of the biblical texts as such, but from the responsible reflection of the human person answering to the divine call. For this kind of reflection, the distinction between God the creator, the governor and the redeemer may be helpful. The first question for this kind of reflection is not "What should we do?", but: "What is going on?" Or: "What is God doing?" Niebuhr does not restrict ethical reflection to the question of right and good, but adds the question: "What is fitting?" The relational approach is not restricted to the understanding of the person but includes the interaction between the situation and the call, to which the person in this situation (the situated person) answers.

A characteristic consequence, related to a concrete ethical challenge, can be seen in the way in which Niebuhr answered to the question that in the early forty's had challenged his thinking about responsibility, namely the hotly debated question of pacifism. Niebuhr opposes a pacifism by principle as clearly as a bellicism out of national pride. He pleads for an openness for "conscientious participation" - if necessary, even in a war, if there is a chance to bring violence under control, not only the violence of others, but also one's own violence.

Repenting self-criticism and conscientious participation are perhaps the two most provoking elements in Niebuhr's reflection on a theological ethics of responsibility. 


\section{VI}

The two theological examples briefly presented in the last paragraphs are in a central point distinguished from the sociological and philosophical concepts, that made "ethic(s) of responsibility" popular in our times. They differ from them in the understanding of responsibility. Max Weber and Hans Jonas are seen as protagonists in their future-oriented understanding of this term. Weber's concept is often reduced to the one short sentence, in which he summarises his concept, namely the sentence on "the maxim of the ethic of responsibility, which means that one must answer for the (foreseeable) consequences of one's actions." ${ }^{30}$ Also in the case of Hans Jonas the whole emphasis of his "imperative of responsibility" lies on the future consequences of present acts, seen under the heuristics of fear. The increase of power in human hands, made available by the progress of science and technology, is ambivalent. It implies new opportunities for the preservation and development of human life as well as for its destruction. Therefore, the responsibility for the future of humankind forms an ultimate ethical imperative.

We find the interest for the future also in the theological concepts of Dietrich Bonhoeffer and H. Richard Niebuhr. Bonhoeffer summarises his thinking at the turn of the years 1942/43 very clearly in the sentence: "The ultimately responsible question is not how I extricate myself heroically from a situation but [how] a coming generation is to go on living". ${ }^{11} \mathrm{He}$ adds in the same context: "To think and to act with an eye on the coming generation and to be ready to move on without fear and worry - that is the course that has, in practice, been forced upon us. To hold it courageously is not easy but necessary". ${ }^{32}$ Niebuhr's concept of "conscientious participation" is also oriented on the question, how life-endangering violence may be stopped, and the future of life may be safeguarded. Both relativize an ethic of principled conviction, taking away from it all kinds of heroic boosting of

30 Weber, 'Politics as Vocation', 360.

31 Bonhoeffer, Letters and Papers from Prison, 42.

32 Bonhoeffer, Letters and Papers from Prison, 50. 
one's self-confidence. But they have in mind all three modi of time - past, present and future. Their integration is inevitable in a relational ethical concept. A time structure, that embraces past, present and future, is central for an ethics of responsibility. Then responsibility is, according to Niebuhr, "the idea of an agent's action as response to an action upon him in accordance with the interpretation of the latter and with his expectation of response to his response; and all of this in a continuous community of agents." ${ }^{33}$ Contrary to a pure ethics of decision we are here confronted with an ethics of communication. Contrary to a purely future-oriented ethics we have to do with an ethics that intertwines the three modi of time: past, present and future. The agent has in his back already conditions and opportunities that concretise the framework of his possible actions. $\mathrm{He}$ or she is confronted with actual challenges. And she or he directs her/his actions to future goals and has to weigh possible future outcomes of present actions. The orientation toward the future is not denied but is embedded in conditions emerging from the past and challenges or opportunities showing up in the present.

The interaction of the modi of time in an ethics of responsibility could be illustrated by three biblical narratives found in the same chapter of the Gospel of Matthew, namely Chapter 25.

One part of this chapter is devoted to the parable of the talents. ${ }^{34}$ It tells the story of a rich man going on a trip, who entrusted his money for the time of absence to his servants. He gave different amounts, according to their ability. When he came back, they returned the money differently. Two of them had invested their talents, the third, out of fear, had dug a hole in the ground to bury his master's money there. For understandable reasons this parable became in Christian ethics a model for the way in which one should make use of the concrete gifts and opportunities related to the personal biography or the capacities of a group, a community or a country. Everyone is confronted with the question how he or she used or will use his or her talents. This is one of the basic questions for any responsible selfevaluation. By the way: the term "talent" has its origin in this parable. The

33 Niebuhr, The Responsible Self, 65.

34 Mt 25:14-30. 
dealing with talents is a good example for the role of the past in an ethics of responsibility.

Another part of this chapter includes the parable of the last judgement. ${ }^{35} \mathrm{In}$ every single person in need to whom we come across we meet the divine judge who identifies himself with all of them. The universal horizon of the last judgement does not paralyse the ability to help the individual person in need before us. Whereas knowing that help for the "generalised other" needs structural and institutional answers that cannot be substituted by individual charity, we have, however, no reason to overlook the "concrete other" in the opinion that his concrete need has exclusively to be answered by structural means. The present reaction to immediate challenges is an integral part of every ethics of responsibility. The preferential option for the vulnerable is a good example.

The first part of this chapter, to which I turn last, is the parable of the ten bridesmaids. ${ }^{36}$ Five of them are called foolish because they forget to prepare for the future, namely the coming of the groom. Five of them are called wise, because they had prepared for the unknown time of his presence. The parable ends with the sentence: "So keep on watching because you don't know the day or the hour".

Ethics of responsibility is nowadays primarily oriented towards the future. And the relation to the future is dominated by a heuristic of fear. Even "Fridays for Future", as fresh and joyful this youth movement presents itself, relates to the motives of anger and fear. But fear is an egoistic sentiment. It concentrates on one's own life conditions in the future, perhaps enlarged to the conditions for one's children and grandchildren. The language of fear is not universal, but particular. It is rather the language of hope that is universal and therefore merits precedence over the language of fear. It is not only the case that our hopes will be disappointed, and our fears will be fulfilled. It may also be that our fears will be falsified, and things will happen that we did not dare to hope. It is now thirty years since the beginning of the changes in South Africa that led to the end of Apartheid. Also, the end of the European division, including the division of Germany,

35 Mt 25:31-46

36 Mt 25:1-12. 
occurred thirty years ago. Both examples show that from time to time our hopes are fulfilled even beyond our expectations. Ethics of responsibility has with regard to the future always to do with conflicting views on risks and opportunities. Risks deserve soberness and well-calculated action. The energy of hope should be invested on the side of the opportunities.

\section{Bibliography}

Bonhoeffer, D. 2005. Ethics (DBWE 6). Minneapolis MN.

Bonhoeffer, D. 2005. Discipleship (DBWE 4). Minneapolis MN.

Dabrock, P., Keil, S., \& Nethöfel, W. (eds.) 2009. Verantwortungsethik als Theologie des Wirklichen. Göttingen.

Dahrendorf, R. 1994. Der moderne soziale Konflikt. Essay zur Politik der Freiheit. Stuttgart.

De Villiers, E. 2018. Revisiting Max Weber's ethic of responsibility. Tübingen.

Fourie, W. 2012. Communicative freedom. Wolfgang Huber's theological proposal. Berlin-Zürich.

Huber, W. 1985. Folgen christlicher Freiheit. Ethik und Theorie der Kirche im Horizont der Barmer Theologischen Erklärung. Neukirchen.

Huber, W. 1990. Konflikt und Konsens. Studien zur Ethik der Verantwortung. Munich.

Huber, W. 2012. Christian responsibility and communicative Freedom. A challenge for the future of pluralistic societies. Collected essays, edited by W. Fourie. Berlin-Zürich.

Huber, W. 2012. Von der Freiheit. Perspektiven für eine solidarische Welt. Munich.

Huber, W. 2015. Ethics: The fundamental questions of our lives. Georgetown University Press.

Huber, W. 2018. 'Ehrfurcht vor dem Heiligen. Zur Aktualität des "Prinzips Verantwortung“'. Pastoraltheologie, 107:411-426. 
Huber, W. 2020. Dietrich Bonhoeffer - Auf dem Weg zur Freiheit. Ein Porträt. Munich.

Joas, H. 2000. ,Interpretation and responsibility: A synthesis of Mead and Troeltsch?' Unpublished paper 2019.

Joas, H. 2000. Praktische Intersubjektivität. Die Entwicklung des Werkes von George Herbert Mead. Berlin.

Joas, H. 2019. 'Re-lecture: H. Richard Niebuhr, The Meaning of Revelation'. Lebendige Seelsorge. Zeitschrift für praktisch-theologisches Handeln, 70:368-369.

Jonas, H. 1979. Das Prinzip Verantwortung. Versuch einer Ethik für die technologische Zivilisation, Frankfurt a.M.

Jonas, H. 1984. The imperative of responsibility. In search of an ethics for the technological age. Chicago IL.

Jonas, H. 2015 2017. Das Prinzip Verantwortung (Kritische

Gesamtausgabe Bd. I 2, 1+2). Eds. D. Böhler / B. Hermann, Freiburg i.Br.

Niebuhr H. R., Pauck, W. \& Miller, P. 1935. The church against the world. Chicago.

Niebuhr, H. R. 1941. 'The Christian church in the world's crisis'. Christianity and Crisis (Summer, 1941):11-17.

Niebuhr, H. R. 2008. 'The responsibility of the church for society (1946)', in The responsibility of the church for society and other essays. Ed. K. A. Culp. Louisville, KY. 62-75.

Niebuhr, H. R. 1945. 'The ego-alter-dialectic and the conscience'. Journal of Philosophy XLII, 352-359.

Ottati, D.F. 2009. 'The Niebuhrian legacy and the idea of responsibility'. Studies in Christian Ethics 222(4):399-422.

Polke, C. 2009. 'H. Richard Niebuhr'. Zeitschrift für Evangelische Ethik, 64:69-72. 
Reuter, H-R. 2015. Verantwortung, in: R. Anselm \& U. H. J. Körtner (eds). Evangelische Ethik kompakt. Basiswissen in Grundbegriffen. Gütersloh. 212-218.

Scheler, M. 1916. Der Formalismus in der Ethik und die materiale Wertethik. Halle a.d.S.

Weber, M. 1994. 'The profession and vocation of politics', in Political Writings (Cambridge UK: Cambridge University Press), 309-369.

Weber, M. 1994. Wissenschaft als Beruf 1917 /1919. Politik als Beruf 1919. Studienausgabe. Tübingen.

West, C. 1965. 'Review of H. Richard Niebuhr, The Responsible Self.' Theology Today, 21, no. 4 (1965):519-522. 